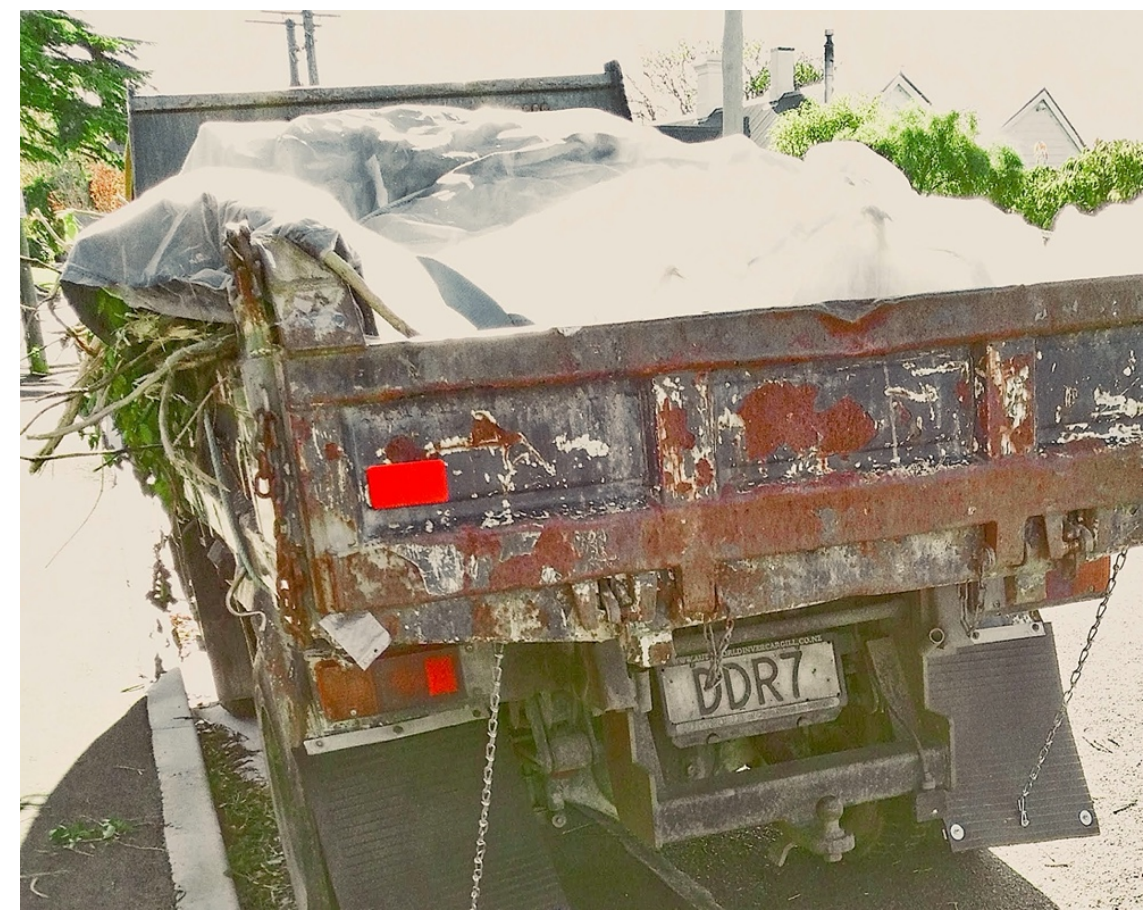

“DDR 7: Found Memory in Aotearoa." Dunedin. 2020. (Photograph by Cecilia Novero) 


\section{The GDR: Thirty Years On, Incidentally Cecilia Novero}

This essay is a critical interpretation of this volume's contributions, which also serves as an introduction. Unlike more straightforward introductions, my text follows its own internal logic, one that draws maps both within and among the contributions, maps that may not be those the contributors had intended. In this regard, I propose that this text be read as a short disquisition on ways to contextualise the GDR, the Peaceful Revolution and postcommunism from within contemporary narratives of revolution, autobiographical evolutions and "ongoingness."

Keywords: 1989, Wende, Tiananmen, Susan Buck-Morss, Donna Haraway, ongoingness, pro-democracy, movements, Hong Kong.

\section{Cartographies I: Visible Maps}

Why an edited volume, yet another one, some may say, on recollecting the German Democratic Republic, at this point and time? The answers to this question, which the contributors to this volume asked at the outset of our collaboration, might differ and might have changed over time. That is, in the extraordinary interval that has passed between the initial impulse for the volume, in June 2019, and its publication, in October 2020. ${ }^{1}$ Yet, the collection's

${ }^{1} \mathrm{I}$ believe that every moment or period of history is singular in the unfolding of the events that pertain to it. Perhaps, then, the use of the term "extraordinary" needs qualification. The moment I am calling 
goal remains the same: our disparate interventions on and around the GDR, the year 1989-1990, and postcommunism (or postsocialism) aim to remember that history is, after all, open. The year 1989-90 has taught us that change is possible, even in troubled times. In manifold and interlocking ways then the memoirs, reportages, interviews, story, and essays in this volume -whether drafted or found again in the thirty years since the end of the GDR and unification-follow two movements and one objective: memories of change, indeed changes or Wenden, on the one hand and changes in and of memory, on the other. Both are considered together and separately as powerful tools for imagining ways to "get on" together.

\footnotetext{
"extraordinary" refers to times (2020 and beyond, most likely) that have been marked by a global pandemic (Covid-19). The pandemic and the reactions to it, this year or at least so far, have made evident neoliberalism's foundations in systemic social, political, racial, and climate injustices. The latter have been heartly felt by all those millions of people who have been affected, in different ways, by the pandemic. What is less extraordinary is who the most affected are, and how they have been affected. Certainly, the devastating effects of the pandemic may not be experienced as extraordinary by those populations that have been suffering under the conditions of inequity and violence brought about by financial capitalism and its shock-therapy methods over long years, whether these conditions are the devastation of Aids or Ebola in Africa, the impact of climate change in Asia and the South Pacific, or the various economic and not economic wars that have not abated in the $21^{\text {st }}$ century and have continued to contribute to the massive flows of refugees fleeing all kinds of destruction around the world. The year we live in -this 2020- however is extraordinary in its historical singularity: not unlike the welcome end of the Cold War. From its inverse perspective, it has brought home, to the "first" world, the confusion, anxiety and fear (rather than the exultation) that until now neoliberal security states were very content to export elsewhere, to leave for "others" (also the "invisible" others within) to deal with.
} 
While the individual texts in this volume offer a variety of approaches, as varied as the locations from which the contributors work, they are all framed here under one overarching question (as it will become apparent in Section II below). Rather than focusing on "what remains" of the idea(l)s of socialism, justice, freedom and democracy, the people's sovereignty, as these principles and values were flaunted during the Peaceful Revolution in 1989, only to be quickly bypassed in the following years, I, as editor, ask: where else might have such demands for alternative "worlding" resurfaced, and in what ways, today? If the constituent collectivities of the sought after and longed for democracies yet to come are plural, diverse and mobile, as testified to by the multifarious movements, and demonstrations on the global squares of the $21^{\text {st }}$ century; these spaces and these times are not to be taken as disparate, but -as I would like to imagine- as entangled actualities.

And this is also true -on another level, of course- about the ways the individual texts in this volume "interact" and dialogue with each other. From this perspective, this collection attempts to show that the imagined textual space of GDR and postcommunist memories the collection maps is less constituted by singular and disparate pieces, neatly organized according to the key questions, issues, and established "genres" that have defined the field. This discursive framework is there; it is, however, there also to be probed, if implicitly. This volume's interventions shape mobile and entangled, perhaps involuntary and flickering -temporary-cartographies of other times as much as of imaginary spaces.

The collection presents acts of "imperfect recollection". It proposes a "hodgepodge" (Giacomo Leopardi called it Zibaldone) of minor pieces, fragments of memories, and 
memories of fragments of Cold war and post-Cold war history that, in the end, come together to draw multiple configurations of the past -and the turnings in it- as starting points for reflecting or refracting possible (near) futures. ${ }^{2}$ As I hope to show below, this is discernible in Seth Howes's conversation with Rainer Görss on Görss's performance and multi-media art. In this interview, the artist insists on the operative notion of "Wertwenden" across his work, and beyond, for example to address past and contemporary questions about the sustainability of aesthetic, political, and environmental economies of extraction and growth. I shall linger on the concept of Wertwenden in the section below, Cartographies II, where I suggest ways to string the texts together that break with the volume's structure.

That the material presence of fragments of memory is crucial in this book is evinced in the return of and to a very real "piece" of the Wall in Anke Pinkert's autobiographical entry, a piece that makes its way into the text through the physical weight it gains in the narrative. More important, this piece of Wall is mobilized -moved and charged with political energy- through an act of material translation, as

2 As I explain below in this introduction, I prefer the term "ongoingness" over "future", following Donna Haraway. In Staying with the Trouble, she writes: In urgent times, many of us are tempted to address trouble in terms of making an imagined future safe, of stopping something from happening that looms in the future, of clearing away the present and the past in order to make futures for coming generations. Staying with the trouble does not require such a relationship to times called the future. In fact, staying with the trouble requires learning to be truly present, not as a vanishing pivot between awful or edenic pasts and apocalyptic or salvific futures, but as mortal critters entwined in myriad unfinished configurations of places, times, matters, meanings." Haraway, Staying with the Trouble: Making Kin in the Chthulucene (Durham and London: Duke UP, 2016), p. 1. 
an act of intrusion into the text. The Wall appears through its photographic reproduction, in Pinkert's text: framed in an "old" photo from East Berlin, first, and then as a floating, fragmented memory -an allegorical ruin out of place, also captured in a photo. The Wall thus promptly leaps off the frames or actual shelves of Pinkert's office, in the US, stacked with books on GDR history.

Chicago-based artist Tom Denlinger's photos in his series Imperfect Recall undo the discursive frames one finds in the orders (the frames) propounded in Museums' collections and their displays. He photographs, among others, the rooms of the Pergamon Museum in Berlin distorting their view through the intrusion within the frame of his dioramas of the messy and transient environments found in the immediate surroundings of the Pergamon Museum. Denlinger's Imperfect Recall series is an apt call to counter and reimagine, from the margins, the cultural and historical practices of contextualisation and integrated ordering at work in these hegemonic, whether old or new, centres of memory.

Denlinger's work in this series has inspired this volume's practices of re-collection: taken individually or together, the contributions do not align or add up to form a whole: this is a collection of imperfect recollections of nonaligned spaces and dates, among other things. With regard to the latter: one finds in the volume texts that were previously shelved. Our hope is to breathe life into them again, by configuring them into new constellations. Not unlike that piece of the Wall in Pinkert's memoir, these exhumed texts paradoxically also happen to re-animate our present. They lift their heads, if texts have heads, to speak in the now of new Wendezeiten prompting us to remember those other -past- contingencies that too presented themselves with urgency when the texts were initially 
conceived. They help us think not just about the past but about the subjective and multiple and, thus, authentically lived genealogies of our present-times, times in which we have "arrived," as Pinkert writes.

Incidentally, to briefly return to Denlinger's Museum Insel photographs, the latter could not have commented, back then when they were produced, on the new about-tobe-completed centre in the centre of East Berlin, namely, the Humboldt Forum in the rebuilt Hohenzollern Castle (opening December 2020). Yet they could be invoked here as a critical tool to poke and probe that most recent restorative, totalizing and re-centring, operation that proclaims Berlin as the financial capital of a new post-Brexit Europe, where the recent past has been done away with (the Palast der Republik, destroyed as pile of asbestos), and the colonial pasts of others are integrated into the spectacle of some whole and healed global history to come.

As this brief survey of the ways the texts in the collection intervene with each other suggests, the volume approaches the year 1989-1990 from a plurality of resonant perspectives. The texts are meant to be read as dialoguing with one another, in multiple combinations; thus, they will surely allow, on the one hand, for less conventional approaches to the periodization of recent German history to emerge, and, on the other hand, to rethink that history through the manifold localities -the sites and space-timesfrom which all actors speak: the contributors, their texts, and the texts they examine.

In our current political predicament, when viable radically democratic alternatives to the crisis of Western political liberalism thin out one more time since 1990, when "illiberal neo-liberist" politics and policies have come to govern the globe, it is urgent that scholars of the GDR, especially, and postcommunism more broadly, remember 
the 1989 Peaceful Revolution from the sites and temporalities of where this revolution might still land or has landed, hence from an expanded spectrum ${ }^{3}$. Bearing this in mind, the volume aims at re-positioning the GDR and its end -if only incidentally and implicitly-within the larger global post-Cold War contexts that have framed our -the contributors'- lives. The collection pursues such aim very modestly, by exhibiting the partiality of our situated, imperfect acts of recollection that remain fragmentary and tangential to the main discourses on the GDR and its legacy. In other words, we approach our own knowing with the knowledge that it is materially implanted within the limitations of our own time's episteme. But situatedness here also implies a self-reflexive move towards one's own thoughts' genealogy, which includes the thoughts not thought, namely the missed encounters and opportunities. When finally seen or found, these thoughts and opportunities must be upcycled -with new conceptual tools, through shifting and shifted frameworks-for pressing agendas.

Before illustrating how the texts in the collection might come together in adjustable clusters, I wish to outline the three tasks of this introduction. At the end, a mnemonic cartography of this volume's special contribution to the GDR and postcommunist studies will emerge. First, I proceed to elucidate the "visible maps" that the texts in the collection draw, picking up the threads of the analyses I started above. Second, in Cartographies II, I trace some of

\footnotetext{
${ }^{3}$ For a map of the increased number of authoritarian governments, see Julian Borger, "Republicans closely resemble autocratic parties in Hungary and Turkey - study," The Guardian, 26 October 2020, npn. Online at https: / / www.theguardian.com/usnews/2020/oct/26/republican-party-autocratic-hungary-turkeystudy-trump Accessed 26 October 2020.
} 
the least obvious connections among select contributions in the collection. Thereby, I carve out possible pathways for reading the volume, pathways that override its immediate organization. Third, in Cartographies III I tackle the original impulse behind the collection. There, I ruminate on how our present conjuncture (i.e., especially the prodemocracy movements in Hong Kong, but one could also think of Black Lives Matter on the one hand, and on the other Trumpism, right populisms in Europe, and Brexit in the UK, etc.) might productively intersect with the frames through which to narrate the GDR, the Peaceful Revolution, and German unification.

In pointing out the crisscrossing of multiple temporalities and the overlapping of apparently distant spaces in the collection, I argue that the contributions might take a first step towards the necessary re-positioning of the GDR and postcommunist memories within important political debates such as, for instance, those concerning postdemocracy (post-politics) versus radical democracy; or the intricacies of nostalgia and populism; the exhaustion of utopian thinking and the (out)burst onto the world stage of interconnected, intersecting, and plural collectivities in their quest for "sovereignty". ${ }^{4}$ Such debates remain, as stated above, tangential to this volume and yet bracket the protracted and open-ended, the ongoing and incidental sentence or phrase that this volume wishes to be.

But first let me turn to the visible maps.

The collection has four parts. Each part groups the contributions by genre. In Part One, a personal memoir drafted in the now of the anti-Trump rallies in November 2019 (Pinkert) precedes a reportage (Peter Barton) of a

${ }^{4}$ See Susan Buck-Morss, Revolution Today (Chicago: Haymarkets Books, 2020), p. 66, 69. 
journey across the still existing GDR just before the elections that sealed its fate, in March 1990. Prior to its publication here, Barton's reportage had been shelved for thirty years. The story by English speaker and German studies scholar, Alyth Grant, had shared the same fate as Barton's reportage -for an even longer time. Barton and Grant's also share a New Zealand perspective, albeit in distinct ways. Grant wrote her auto-fiction, "1982," just after she had completed a short stay in the GDR in that year. In a gesture of true kindness, of engagement as demonstration of respect and response, Grant's story, drafted in the foreign style and idiom of writer Helga Schubert, rather than Grant's own, was conceived as a dialogue with this author, whom she had heard talk in Leipzig. ${ }^{5}$ Speaking in the language of the other, Grant's story -the sole fictional contribution in our volume-is an example of lived cultural translation that crosses not only spatial and political borders, but also temporal ones. The

5 On kindness as related to "making kin" and response as responsibility, see Donna Haraway: "I first started using the word "kin" when I was in college in a Shakespeare class because I realized that Shakespeare punned with "kin" and "kind." Etymologically they're very closely related. To be kind is to be kin, but kin is not kind. Kin is often quite the opposite of kind. It's not necessarily to be biologically related but in some consequential way to belong in the same category with each other in such a way that has consequences. If I am kin with the human and more-than-human beings of the Monterey Bay area, then I have accountabilities and obligations and pleasures that are different than if I cared about another place. Nobody can be kin to everything, but our kin networks can be full of attachment sites." Steve Paulson, "Making Kin: an Interview with Donna Haraway," Los Angeles Review of Books, December 6, 2019, npn. Online at https: / / lareviewofbooks.org/article/making-kin-an-interview-withdonna-haraway/ Accessed 23 October 2020. 
crossing of temporal "barriers" that Grant's story announces recurs in Part Two.

The volume moves from the more personal accounts and interviews in Part One and Part Two to the academic essays in Part Three and Part Four; in turn, however, the academic essays take the personal as their object of study. One example are Daniela Nelva's analyses of Stefan Heym's autobiographical annotations on and revisions of the events of the $17^{\text {th }}$ of June 1953 (in addition to Nelva's examinations of Heym's fictional and journalistic renderings of that other momentous, if repressed, date in GDR history). Lifewriting may indeed be found to be a common denominator among most of the contributions. In one way or other, the autobiographical element intersects, clashes, negotiates with historiography, within most texts, taken individually, and across the majority of the volume's parts. In this sense, the self-reflective focus on the personal in these texts -that present the memories described through new temporal frames-engenders mnemonic palimpsests that break with traumatic patterns of compulsive repetition of suffering or loss. As Andreas Huyssen writes: "Memory, whether individual or generational, political or public, is always more than only the prison house of the past." ${ }^{6}$ The contributions take this statement to be programmatic.

An exception is Part 3 devoted to material culture. Let me thus sketch the issues that arise from the essays gathered here, before returning to how personal narratives or narratives of the personal cross-over from Part One to Part Two and Part Four. In her contribution, Sara Blaylock examines the Wende Museum in Los Angeles, yet another translation of sorts of GDR everyday culture. According to

\footnotetext{
${ }^{6}$ Andreas Huyssen, Present Pasts: Urban Palimpsests and the Politics of Memory (Palo Alto: Stanford UP, 2003), p. 8.
} 
the author, by materially re-surfacing outside Germany, the Wende Museum offers an experience to its visitors that is transformative of otherwise potentially entrenched and embittered forms of nostalgia. The latter manifests more explicitly in the reception of similar museums at home, on German territory. The GDR ideological mementos or obsolescent commodities on display in museums of everyday culture could turn into vehicles for telling and sharing stories through which the "lost" but, more crucially here, "dismissed" or unrecognized past could be mourned. In fact, the absolute appropriation of such items from within the hegemonic discourses of (i) GDR society as always already totalitarian, and (ii) Eastern nostalgia or Ostalgie, on the other, has reduced the objects' potential to resist such master narratives, dismissing them once more. This potential, according to Blaylock, is revitalized in LA.

While being distant from Germany in many ways, this city is in no way a blank page or a neutral territory. The Wende Museum taps into the strong cultural and art connections between LA and Germany. These have been actively and widely cultivated since at least the settlement here of many exiled German philosophers, filmmakers, and writers during the Nazi regime and the Second World War. The Wende Museum thus finds its location among some of the largest collections of German art, archives and material culture in the world, outside of Germany. To mention a few: The Getty, LACMA's Rifkind Collection, the Museum of Contemporary, USC, and the Huntington Library in San Marino. ${ }^{7}$ In displaying its collection of GDR objects, the

\footnotetext{
${ }^{7}$ Justinian Jampol, "GDR on the Pacific: (Re)presenting East Germany in Los Angeles," in Art Outside the Lines: New Perspectives on GDR Art Culture, edited by Elaine Kelly and Amy Wlodarski (Amsterdam, New York: Rodopi, 2011), p. 254.
} 
latter fall into a discursive network that ensues from such past, and this allows for novel critical readings of the objects in question, pushing their reception beyond the purview of the German discourse on nostalgia. At the same time, I argue, one would have to ask what political meanings might lurk behind the preservation in the US the epicentre of consumer culture and capitalism during the Cold War- of the everyday culture of the GDR. This especially considering that the GDR is the country that more than other socialist countries has been taken as the symbol of the failure or, rather, the defeat, of real existing socialism, a defeat that, according to these accounts, would make real capitalism, and the US, the victors of the Cold War. ${ }^{8}$

In considering the Wende Museum, perhaps then one ought to play up rather than play down the political aspects that emerge from the encounter or clash of the contexts produced by the German history of exile, Cold War, its end and the end of real-socialism, in L.A., and L.A.'s own versions of that history. This may help to take note of the intricacies that bind the material representation of memory with the colonial/ethnographic impulse that still saturates some such representations and displays, especially in the global museum culture of the present day. Be that as it may, Blaylock's essay stimulates a whole series of other important questions, including about the crucial post-1989 discourse of nostalgia. Following Dominic Boyer's argument on nostalgia, we may ask whether the siting of the Wende Museum in L.A. may bring to the fore first and critique second the deep-seated and reiterated patronizing

\footnotetext{
${ }^{8}$ Christa Wolf deals with such issues in City of Angels: Or, The Overcoat of Dr Freud. Translated by Damion Searls (New York: Farrar, Straus \& Giroux, 2013).
} 
Western civilisational framing of nostalgia. Such discourse is for Boyer profoundly Western European and relies on defining nostalgia as an essential quality of the irrational Eastern European populations. Western Europe thus labels nostalgia as reactive and reactionary, just as it labels such populations as "backward": a property of the Orientalized other that is allegedly stuck in the past, nostalgia's function would then be to prop up Western Europe's selfproclaimed orientation towards the future. ${ }^{9}$

Museums of GDR everyday life objects have become the current arena where the struggles for hegemony of a contested past take place. In contrast, actual locations, sites or buildings where life took place, such as the Interhotels that were scattered across the major cities of the GDR, have almost entirely disappeared from today's landscapes of GDR memories. Silvia Ulrich reconstructs the twisted logic and paradoxical existence of these luxury hotels for foreigners and for special GDR guests, at the heart of a socialist state that made vacation for all one of its policies. In Ulrich's reading, the IH gave rise to a sheltered "state of exception" within the GDR: accordingly, these hotels capitalise on the past and decadent bourgeois tradition of grandeur ascribed to legendary German Hotels, which, in

\footnotetext{
${ }^{9}$ Dominic Boyer writes: "The idea that nostalgia "belongs" somehow exclusively or even especially to Eastern Europe is pernicious, an aspect of the persistent allochronization (that is, temporal displacement) of Eastern Europe into the imagined margins of the urban, industrial, and scientific centres of Western European modernity. According to these centres, how could Eastern Europe be anything else other than pastfixated? For one thing, its pastness is genetically constitutive of Western futures."(p. 22). Boyer, " From Algos to Autonomos: Nostalgic Eastern Europe as Postimperial Mania," in Post-communist Nostalgia, edited by Maria Todorova and Zsuzsa Gille (Berghahn Books), pp. 17-28. Online at https://www.jstor.org/stable/j.ctt9qd8t4.5 Accessed 20 October, 2020.
} 
the GDR's official culture, was rejected. Tradition, clothed in socialist modernism, is instrumentalized by the State in order to institute the $\mathrm{IH}$ as an island for capitalist and consumerist exchange. Its sole purpose: procuring much needed foreign currency. These are sites of "legitimate illegitimacy" (for example where prostitution is permitted, in contradiction to its prohibition in the GDR) where the State "betrays" its people to "save" its people. Here, guests and enemies are one and the same, and, here too, as Ulrich shows, the State sells its own ideology on the one hand, in order to sustain it, on the other. Carrying out a careful examination of the ins and outs of how $\mathrm{IH}$ operated, including an analysis of the exclusion, for the most part, of their representations from GDR literature, Ulrich concludes that the IH's modus operandi illuminates how the GDR had always already "sold out" to Western Capitalism. In one sense, this analysis suggests that both "dreamworlds" Western real capitalism and real socialism-were intricately bound together, as history has proven; in another sense (and to follow Buck-Morss), it reveals that each system, as it eventually developed historically, "contained an inherent contradiction, a destabilizing tension, a threat to legitimacy that was not caused by the enemy 'other.' This tension had its source, rather, in the fact that each system of political imaginary was deployed within economic and social conditions that were, at least potentially, in fundamental contradiction to that system." (2000, p. 39) So, as Buck-Morss concludes and Ulrich proves with her analysis of Interhotels in the GDR, "If the era of the Cold War is over, it is perhaps less because one side has 'won' than because the legitimation of each political discourse found itself fundamentally challenged by material developments themselves." (Ibid) 
Above I concentrated on the essays in Part Three because, for their focus on material culture, they stand apart from the others in this collection. Part Two, titled Tuning In: Words, Sounds E Images, picks up the thread of the discussion on the autobiographical and the personal that opens this volume. Here artists and writers reflect on their life and work: the above-mentioned artist Görss, writer Christoph Hein, and Laila Stieler, a screenwriter who collaborated on several occasions with film director Andreas Dresen. As it happens, Stieler engages life-writing in her biopic about the GDR songwriter Gerhard Gundermann -deceased in 1998. His life is the subject of Dresen's most recent film (Gundermann 2018), about which Stieler talks in her interview with Max Leinkauf, here reproduced in English for the first time. To close in on this figure, the volume includes David Robb's attentive musicbased analysis of Gundermann's songs, a study that is also informed by Robb's own experiential perspective, that of a musician who also happened to meet Gundermann. The biography rather than the works of this song-writer found a not uncontroversial reception after the Wende once it turned out that Gundermann had collaborated with the Stasi for a number of years. The contradictions and dilemmas inherent in this life are left purposefully unresolved in the fragmented narrative structure of Stieler's and Dresen's biopic film. A similar strategy of biopoiesis informs Christa Wolf's experimental 1996 novel, Medea. Stimmen, analysed by Brangwen Stone's in Part Four.

For some critics, Wolf's novel was this author's mythologically clothed attempt to deal with her "scapegoating" by the German media. On that view, in writing Medea, Wolf works through the attacks received first during the Literaturstreit following the publication of 
Was bleibt in 1990 and, then, subsequent to the revelations in 1993 about her brief collaboration with the Stasi as an IM (unofficial collaborator), in her youth.

In her analysis of Medea. Stimmen, however, Brangwen Stone does not take this road. She considers Wolf's text as the fruit of Wolf's enduring critical engagement with patriarchy. More specifically, on Stone's view, Medea underscores how patriarchy is first part and parcel of the sacrificial dynamics of state formation in Western Civilisation; and, second, how it is imbricated in ongoing rather than closed- colonial forms of oppression, domination, and identity formation. Wolf's experience of German unification functions, in Stone's examination, as the backdrop for Wolf's staging of such power relations. Stone proceeds to scrutinize such relations through the lens of postcolonial theory, in particular Said on Orientalism and Bhabha on hybridity. Medea, Stone argues, represents the hybrid subject who cannot be accommodated in either Colchis or Corinth or by male/female or rational/affective categories. But if Colchis and Corinth are analogues of the two Germanys, one may ask, does that mean that her (Medea's) transgressive potential has departed now that the history of reunification seems to have been settled? (Or perhaps the "barbarians" are still there in the East?). In any case, Stone's vision of the Medea-hybrid as an opportunity that is perhaps always lost (as a permanent lost cause) is provocative. It may possibly invite the reader to find the auto-socio-biographical element in the novel. From within this framework, the novel serves as a foil for Wolf to come to terms with her changed position with respect to the functions of literature in unified Germany. ${ }^{10}$ Jörg Magenau in his biography of Wolf quotes the writer as saying at the

${ }^{10}$ I owe these thoughts about Stone's essay to Peter Barton. 
time of the novel's publication, "I don't believe that an author or literature in this society can effect anything as far as changing the social relations is concerned."11 As the biographer concludes, drawing a close parallel between Medea and Wolf, all that is left for Wolf in the new Germany, at this point and time, is freedom, without messages to convey, without objectives to be met (443).

The experimental polyphony that makes up Wolf's postunification novel -as contested as the argument about such polyphony might be- contrasts with the choral voices singing in tune in the classic 1968 GDR musical film Heisser Sommer (Hot Summer). Ruth Crawford's essay discusses the film as the site of negotiation between the State and the GDR youth, at a crucial moment in both Eastern Europe (the Prague Spring), and the anti-Vietnam student movements' protests across the Western world. Crawford identifies a potential subversive element in the film in what she views as its "failed romance" -or, according to Hollywood musicals' canonical narratives, the lack of a happy ending as the resolution of conflict. The romance among two of the main protagonists fails because on the one hand the film starts from the perspective of an always already achieved wholeness between individual and collective, hence no real conflict is at the heart of the film; on the other, because the romance, when it occasionally appears to take off, must be extinguished as a threat to the collective. But the romance's "failure" to convince due to its lack of closure, Crawford notes, is also what makes the film an object of revivals in theatres today, both on the stage and on the screen. These nostalgic rehearsals of the film involve its active embodied rewriting, a rewriting that may

${ }^{11}$ Jörg Magenau, Christa Wolf. Eine Biographie, Berlin: Kindler 2002. 
also express the nostalgia for the cinema as itself the space for the shaping and living of imaginary collectives.

As foreshadowed in this brief excursus, each text and each part in the volume intersect across multiple pathways -indeed dialogue- with the others, whether one thinks of autobiography, biopics, and memoirs; or of narratives of and about the displacement of GDR history and culture onto the larger post-Cold War world map; or still, more subtly, of the forgotten, repressed, or simply unconventional temporalities in, of and beyond GDR history that might surprisingly shed new light on 19891990. My task in Cartographies II, in this essay, is to suggest those links and overlaps among the chapters that chart the least visible maps the chapters draw.

Before doing so, two notes are important here: the first is a note on method that, in fact, is first of all a note on footnotes, specifically the footnotes accompanying my own text. ${ }^{12}$ The second is a note on my recourse to the term "incidental" throughout my text and most notably in the title of this essay, "The GDR: Thirty Years On,

\footnotetext{
${ }^{12}$ Where Anthony Grafton's witty and erudite history of the footnote could be instructive here, my anachronistic recourse to footnotes is prompted less by the desire to revamp the authority of the scholar's professionalism, or to flaunt erudite knowledge, or still the labor that went into the crafting of what might appear, to the eyes of colleagues sharing "my" discipline, a banal text in the end. I don't intend to adopt footnotes here to slow down the movement of reading making the text impervious, and pedantic, less accessible. Footnotes have de facto been eliminated from current academic publishing - and rightly so, perhaps, if the move indeed facilitates accessibility (less so if one equates accessibility with marketability). Rather and in absolute contrast to inaccessibility, my recourse to footnoting is meant to open the text up to a plurality of discourses that are urgent and that must interact, in whatever way. See Grafton, The Footnote: A Curious History (Cambridge, Mass: Harvard UP, 1999).
} 
Incidentally." As far as the footnotes go: I let myself be inspired here by Buck-Morss's running hypertext in the first chapter of her study Dreamworld and Catastrophe: The Passing of Mass Utopia in East and West. ${ }^{13}$ In that chapter, she lays out her theoretical argument in the main body of the text only to open that text up to, as she writes, "historical time by hypertext links to a series of keywords that provide partial narratives along its lines." (Buck-Morss 2000, xv) The hypertext she refers to occupies the place that usually is taken by footnotes. In my case, footnotes are the hypertext: I preserve their "classical" format but I would like them to be read as a running hypertext that crossreferences multiple discourses, including some that one may consider "im" and "non" pertinent. Furthermore, in my long and occasionally very long footnotes, not unlike Buck-Morss's hypertext, I too provide some conceptual keywords. Yet, my hypertext is more modest in its scope and intents than Buck-Morss's. It proposes less to "rescue historical data threatened with oblivion" (Ibid) than to experimentally criss-cross my observations on remembering the GDR and German postcommunism with concepts and frameworks I borrow from scholarly fields other than German Studies (such as, for instance, extinction studies). Footnoting is my attempt to bring diverse bodies of knowledge in conversation; and to invite others to follow the surprising avenues, and provocations, they might open.

With regard to the term "incidental," I would like to mobilize it, first, in its current meaning of "by the way" (rather than "along the way"), which I wish to "enlist" to the purposes of our provisional zigzagging in and out of

${ }^{13}$ Susan Buck-Morss, Dreamworld and Catastrophe: The Passing of Mass Utopia in East and West (Cambridge, Mass and London: MIT Press 2000), Part I (chapter 1), pp. 1-39. 
the major frameworks for interpreting the GDR, and its end; second, but to the same effect, by ways of an invented etymology, one that imaginatively discovers in this adjective the biting ability of those animal teeth known as "incisors". The volume hopes to bite into the present and past -what I believe is still the "hot matter" of the end or rather ongoingness of the idea of a democratic socialism with small yet incisive and, in this sense, biting remarks (not only does the incisive in "incidental" reminds one of teeth, but also the "dental" in it: the Latin word for tooth is dens, dentis).

\section{Cartographies II: Re-imagined Maps or Playing at Making String Figures ${ }^{14}$}

A proposal for a few ways in which the texts in this collection might interlace.

International, Situated and Interventionist Writing: Starting from our Biographies

The International: Certainly, a play on words and an obvious, if tongue-in-cheek, reference to the spectre of socialism! Jokes apart, I invoke the "international" as an empirical fact informing the very structure and soul of this volume, something I wish to play up, not down: I

${ }^{14}$ On string figures and Donna Haraway's particular use of "SF", see the blog by "Museum Fatigue". Importantly, if only coincidentally, for the purposes of this volume, the author of this blog describes the focus of their research as China and postsocialism. The blog on SF may serve as clear and practical guide to think (with) string figures in the new Covid-19 era: https://museumfatigue.org/2020/04/09/makingstring-figures-amid-the-troubles-on-zoom/ Accessed 23 October 2020. 
mentioned before that the collection aims to reposition the discourse of post-GDR culture and socialism within parameters that, while yet to be drawn, nonetheless exceed those of Europe. One obvious way in which this volume pursues this goal is through our "situated" histories in multiple locations and contexts of knowledge production: the contributors are scattered around the globe.

Furthermore, a few of the contributors have changed our locations multiple times over the last three decades, which requires re-viewing, renegotiating and altering one's local frames of vision, including the tenets of our past -and present- elaborations of GDR, Germany and Europe, the main objects of our scholarship. At the same time, residues of that acculturation "elsewhere" have persisted, rendering our numerous acts of translation -the conditions of our knowledge-production- across times and cultures all but transparent.

The interventions here, thus, knowingly embrace and expose themselves as fragmented and fragmentary, in fact partial, which is not to say that they are "subjective" or unfounded..$^{15}$ Accordingly, by reflecting from our locations in the present on the memories we have, those we might have had, and those that will come (see Pinkert's "Arrival"); or by finding again, almost literally unearthing old texts (Grant's story "1982"; Barton's

${ }^{15}$ Christa Wolf coined this concept in 1968. As she put it, subjective authenticity is the prose writer (the author)'s fourth dimension. While the contributors to this volume are not "authors" as Wolf intended this figure in her definition of "subjective authenticity," some salient features of the concept apply to the texts in this volume, especially the most autobiographical. See Christa Wolf, "Subjective Authenticity: A Conversation with Hans Kaufmann," in Responses to Christa Wolf, edited by Marilyn Sibley Fries (Detroit: Wayne State UP, c.1989, 1993), especially, pp. 59-62. 
"Schubladenreportage", 1990; Cecilia Novero's "Willenbrock-Interview" with Christoph Hein, 2008), this collection deliberately rejects final conclusions and resist definitive assessments of failure / success in history.

It equally makes no secret of the fact that our texts -as our biographies- are provisional statements (think of the interviews in the volume). Furthermore, it is by virtue of their "instability" or process-based openness, to borrow from the art world, that they might function as examples of "interventionist" writing (Wolf 59). In this way, they try to "stay with the trouble," which, following Donna Haraway, involves the ability to respond to -or the response-ability towards-a singular thick present of entangled situations, to the moment that in its singularity however never means "self-presence": ${ }^{16}$ 1989-1990, but also all those other dates that the texts gathered here consider. Through these other times, the stories in this collection diffract that momentous year, and offer an alternative or less conventional periodization of historical events.

\section{Intersecting Multiplicities: Where We Meet}

It is with partial vision, and the awareness of this, that the texts collected here incidentally encounter some of the key issues or topics that have preoccupied and defined GDR and postcommunist scholarship since the Wende. To name just a few: the proliferation of autobiographical writing in the years of transition from real-socialism to realcapitalism; the debates about what constituted official or

\footnotetext{
${ }^{16}$ See Eduardo Kohn, "What kind of world can what kind of we world? Staying with Donna Haraway's Staying with the Trouble," Dialogues in Human Geography 8 (1), pp. 99-101.
} 
unofficial, complacent or oppositional culture in the GDR, a debate that pivoted mostly on the Stasi; the questions elicited by the social and cultural phenomenon of nostalgia or, as it is commonly known, not unproblematically, as Ostalgie (here the literature has spanned fields from sociology, anthropology, museum studies, media and visual culture and the humanities as a whole); finally, the spectrality of the GDR, its renewed haunting especially in the literary production of either aging authors, who have lived in the GDR before unification, or a younger generation of writers. For the latter, as discussed in the scholarship produced under the rubric of Memory Studies, haunting may manifest itself as a kind of prosthetic memory, or-alternatively-in the encroachment of natural history onto history, the morphing of GDR memory into fossil.

Having already illustrated the workings of the auto/biographical across the volume in Cartographies I, but only having mentioned there how some of our texts tangentially touch on the discourse of nostalgia, I will linger here on the latter focusing on how the texts in question might intersect with that discourse, advancing a creatively critical perspective. To this end, I will borrow instrumentally and freely from Görss's the concept of Wertwenden.

As Howes and Görss discuss in their interview (Part Two), Wertwenden refers to "turns/changes" in values, to those economic, political, and cultural transformations that, as Howes explains, the artist lexically connects to THE Wende, to the year 1989-1990. The Wende is multiplied and refracted in his art as if through temporal prisms that illuminate the sedimentation of certain values in particular environments, in the humus that is most consonant to these values' growth and spread. But such humus may find itself 
under stress at times, so that -like bacteria or spores (Görss's Biobilder, see the interview), those values die out. Like those same bacteria and spores, under favourable conditions values may come back alive, reproduce, and spread again, if in new environments. So, for Görss the Wende -as aptly remarked by Howes-figures in a number of other apparently disconnected contexts, for example climate change. The call for attention to be paid to the environment -which was marginalized and could not grow as a culture for instance during the race to industrialization in socialist countries, is now making itself heard from within the new context of the unsustainable capitalist economy of growth. This "culture" is now growing, demanding and effecting, so Görss hopes, change. If not exactly in the same way Görss may intend it, the concept of Wertwenden is still useful to understanding the purposes of this volume: on the one hand, to see where some among the submerged values or cultures (bacteria, spores etc) from the GDR (say: work) and the Wende (democracy) may find or have found a fertile terrain in the now of our time to make their come-back and grow into new cultures (of radical democracy); and second how indeed artists and scholars, cultural operators and intellectuals etc may actually transvalue, and put to work old values fallen in to different ends (upcycling, recycling, twisting and changing, creating new environments for these to grow sustainably rather than exponentially).

These ideas inform not only the twists and turns, the points of connections, the overlaps but also the disconnect among the contributions. In other words, the texts in the volume share a focus on both the changes in values and their implications, in their respective objects of study. And, the contributions also intersect by bouncing questions off each other that might make the reader see those changes in 
values as they manifest through the comparing and contrasting of the contributions themselves. To use the title of one of Görss's photographs reproduced here, the reader learns to see such changes as they permeate the collection, through a Sehschlitz der Zeit (Howes's translation: "A Crack to see Time"). The contributions thus form open environments (dialogic fields and contexts) where through cross-pollination new reading and writing cultures flourish, for example imbuing nostalgia with new meaning.

The environments or planes I examine here are formed by intersecting axes. One is the "music" axis that connects, for example, the film Gundermann with the musical film, Heisser Sommer. Additional axes could be detected to map yet other imaginary critical cartographies thus juxtaposing alternative readings or planes to those drawn by the volume's organisation in Parts, as I have discussed in Cartographies I. Besides the "music" axis, another axis around which some of the essays and interviews could come together is the "work" axis. This is constituted by all the practices of labour, and craft to which the texts considered in the contributions may allude. Significantly, this axis also crosses the music axis, further complicating, for example, the interpretations leaning towards nostalgia of two of the three films discussed in this collection, namely Gundermann and Heisser Sommer, as mentioned above. ${ }^{17}$ In

17 Novero's interview with Christoph Hein on his novel Willenbrock in
2008 is published here for the first time. Andreas Dresen adapted the
novel into a film, with a script by Laila Stieler. Novero's conversation
with Hein focuses on the novel. Yet, it was prompted by Dresen's film.
As explained in the preface to that interview in this collection, at the
time, Novero considered the legacy of GDR literature and film in
postunification Germany through the concept of minor literature, more
specifically the lens afforded by adaptations to the expression of
"collective enunciation." For more recent work along these lines, see 
the latter case nostalgia is not located in the text, of course, but in its "return" in postunification Germany. An additional pivot for an additional axis is the term "arrival", invoked at the end of Pinkert's memoir, a term that resonates -from very distant shores- with the early 1960s GDR tradition of Ankunftsliteratur.

Pinkert's memoir operates a Wertwende of the notion of "arrival" and the genre of "arrival literature" as a whole that genre of GDR literature focussed on the integration of the individual into the working collective. The transformation of the autobiographical subject in Pinkert's text could be re-framed by taking a look at other such transformations in the collection. For instance, one could do so through the lens of the film Gundermann, which also establishes another crossing of axes. The film -set in Hoyerswerda, a new model city of socialism where Brigitte Reimann's novel Ankunft im Alltag (1961) also takes placeitself rewrites and breaks away from the idea of "arrival" as "final destination", where the latter involves an organic process of integration. ${ }^{18}$ Through highlighting contradiction upon contradiction in the life and work itineraries of the communist song-writer, singer and excavator operator, Gundermann arrives in multiple times

the PhD thesis by Derek Schaefer, East German Literature in the 21st Century: Minor Literature and Alternative Memory (Chicago: University of Illinois, 2016).

${ }^{18}$ See Hunter Bivens's essays on Brigitte Reimann, and on "work." On Reimann, Hoyerswerda and the project of socialism with regard to the built environment, see "Our Short Life: Building and Dwelling in Late Socialism," npn.

Online at: https: / / ecommerce.umass.edu/defa/sites/default/ files/Our\%20Sho rt\%20Life $\% 20-$ \%20Building $\%$ 20and $\%$ 20Dwelling $\% 20$ in $\%$ 20Late $\%$ 20Socialism $\% 281 \%$ 29\%20copy.pdf Accessed 25 October 2020. 
and in multiple places, always without leaving Hoyerswerda. Arrival multiplies here into constant renegotiations with oneself -one's selves in time- and with power. For example, and bluntly put, achieving the socialist, all-round personality, of head, heart and hand, as the slogan went, meant that the engaged Gundermann was kicked out of the Army, belonged to the SED, only to feel he had to critique it and its functionaries, worked for the Stasi, but then ended up the object of Stasi observation. ${ }^{19}$ The only steady thing in his life was his work: as miner and excavator operator, and as musician, the former job fuelling the second. The film skilfully edits shots of Gundermann at work in the tiny cubicle of an immense, dinosaur-like machine moving at pace on the open-cast mines, in a devasted crater-full moon landscape, with scenes of him scribbling there his songs while the very same play in the background. Art seems to integrate well with work and vice versa here, and accordingly the film could be viewed as a positive depiction of the ideology of slogans such as "reach for the pen, comrade!" that accompanied the Bitterfelder Weg and the emergence of Ankunftsliteratur. Yet, to dispel such interpretation reveals that the film's focus is on fatigue, fatigued faces and bodies, and Gundermann's labouring through such fatigue, until his death by exhaustion.

The "arrival" axis thus crosses here into the music axis, via the pivot "work," thereby complicating the

${ }^{19}$ Not unlike in this Christa Wolf's life-itinerary, although Gundermann lived a much more marginal and precarious life, despite his songs' popularity in the GDR and during the early Wende years until his death in 1998. See Andreas Leusink, Gundermann

Von jedem Tag will ich was haben, was ich nicht vergesse ... Briefe, Dokumente, Interviews, Erinnerungen (Berlin: Christoph Links Verlag, 2018) 
conventional values associated with one or the other keyword, e.g. Ankunft and work, as these were understood from within the real socialist framework. In this sense the film exhausts the possibility of reviving the humus necessary for the revivification of the culture of "arrival" quite literally through images of arid, and coal-polluted earth, despite the fascination these images ooze.

While preserving the desire to live full lives for a later day (our day, in which the film is filmed), the film translates its main character's passionate exhaustion onto the exhaustion of the socialist state. Passionate exhaustion is a distinct way through which this film sets itself apart both from the grey depictions of the extinction of the GDR, or socialism that have become canonical since the Wende, in many films; and from the happy-go-lucky images of the GDR or, for that matter, unified Germany that have made their ways in popular comedies. In contrast, Gundermann turns nostalgia into a cluster of tensions, an unstable and anxious aggregate of desire, energy, creative labour and collectivity as ongoing aspirations of a "good life" on the one hand, and dissipated and desiccated opportunities / concepts on the other.

How the film might turn those desires into new arrivals -in the plural-has to do with work, yet again: the work that went into the film's laboured production, over many years, as Stieler mentions in her interview; the work of recrafting the music: Gundermann's songs were remastered, adapted, interpreted and sung in the film and for the film by various musicians, including actor Alexander Scheer, a band from West Germany, and Dresen himself. Collaboration at all stages was required. ${ }^{20}$

${ }^{20}$ Dresen remarks: "I wanted to share that feeling of being profoundly touched, that's why there is so much space given to the songs within 
Furthermore, and importantly here, both Sheer and Dresen have been staging live performances of Gundermann's songs in public venues across Germany since the film's release. ${ }^{21}$ The film has jumped the frame of the time and space that befit it, opening up new possibilities to embody re-valued values, such as, among others, collaboration and collectives.

Considered from this point of view, Dresen's film may serve as a filter through which to look at Heisser Sommer, some of whose tenets Gundermann re-evaluates, i.e. appropriates and changes. For example, one could analyse the different filmic values the two films ascribe to work: Gundermann takes the rural and industrial (freight rail transport) backdrop in Heisser Sommer and quite literally puts it to work in his film, first by inserting the workers into that landscape and, second, by focusing on Gundermann's song-writing and singing as inextricable from that landscape. While romance, as Crawford argues in her contribution, must be "extinguished" in Heisser Sommer in the name of the collective, Dresen's film -and Stieler's script here plays a key role-shows how the special romance between Gundi and Connie allows for various collectives to form with and around them, at different times. Finally, if

the film. But it was important to us that they were revised and that we didn't just play them back verbatim. They are a kind of cautious adaptation. Jens Quandt supervised the music recording, and I chose Gisbert zu Knyphausen's old band. They're all "West musicians" who didn't know Gundermann, and were excited to explore and adapt the songs." European Film Awards Website: https: / / europeanfilmawards.eu/en_EN/film/gundermann.13137202 $\underline{0}$. Accessed 26 October 2020.

${ }^{21}$ See https://www.berlin.de/en/tickets/concerts/alexander-scheerandreas-dresen-band-gundermann-fba5645e-6f1e-407e-b77261e70df9e70b/ Accessed 26 October 2020. 
Gundermann's music is being proposed live on stage today thus re-directing nostalgia into collective performances that perform -call into being-new, varied, different collectives in the present; in turn, the restaging or rescreening in public venues of Heisser Sommer remind us that these in-flux collectives always long for a public space where to become, as Crawford maintains.

If intersecting these three axes (arrival, work and musicfilms) allows nostalgia to be opened up to different evaluations (values), are there other constellations of thought in this collection that might afford a different angle on the Wende Museum, a critical one perhaps? This could be the axis that connect the Wende Museum, Denlinger's photos of museums, and Görss's own Underground Museum in Berlin, in Howes's words, his "blended archive of artifacts and artworks." I won't embark here on the critical and creative ramifications that such cross-readings may engender. I will leave it to the reader to imagine their own and in doing so to carry on playing the game of string figures.

\section{Cartographies III: Changing the Maps, Change We Must}

The idea for the following collection sprung less from the imminent anniversary of the Fall of the Berlin Wall, in November 2019, which nonetheless the contributors also knew had to be at the core of our academic attention; after all, most of the authors in the collection are German Studies scholars, with a stake in the study of GDR and postcommunist cultures and societies. Rather, the idea that animated the volume was and is the sentiment that the legacy of the Peaceful Revolution in Germany may be better understood in the context of a larger global constellation. 
The motor that really propelled this collection was the resurgence of the Hong Kong umbrella movement (2014) in June 2019, following the second reading of a controversial extradition bill with China. That month also marked another, sombre, $30^{\text {th }}$ anniversary. I am referring to the Chinese People's Liberation Army's violent suppression of the Tiananmen Square protests on June 4, 1989. While both events -i.e. the German Peaceful Revolution on the one hand and Tiananmen on the other-and their anniversaries are tinted in very different colours, in my view, these histories, are and have been co-joined since then, as if by a chiasm. In recent years, the Chinese political authoritarianism has tightened its grip on its labouring population in the name of which the government has relentlessly pursued global (capitalist) expansion. As Susan Buck-Morss comments, the benefits of such authoritarian, communist and consumer-oriented politics are however reaped by "a wealthy elite that integrates willingly into the global capitalist class." (SBM 2019, 20) In Cora Chan's words, the repression of the democratic movement on Tiananmen square in 1989 had "marked China out as an exception in the chapter of world history that saw the fall of international communism." And, in doing so, it had also consolidated "the mistrust between China and Hong Kong into an open ideological conflict - Leninist authoritarianism versus liberal democracy - that has colored relations between the two [my note: China and Hong Kong] since then." ${ }^{22}$ Such mistrust only increased in

${ }^{22}$ Cora Chan, "Thirty years from Tiananmen: China, Hong Kong, and the ongoing experiment to preserve liberal values in an authoritarian state" (2019) 17(2) International Journal of Constitutional Law 439-452. Available at https://ssrn.com/abstract $=3453130$. Accessed 9 October 2020. 
2014, when China proposed a reform of the electoral law. Through it China's reabsorption within its own of Hong Kong's largely liberal (if not democratic) jurisdiction, scheduled for 2047, started to pick up speed. It was at this point that the pro-democracy movement, in the making since Tiananmen, occupied, this time, the streets of Hong Kong. A younger and even more energized second wave of protests for the respect of the democratic rule of law took over the public squares of Hong Kong in June 2019.

It was then, in light of these events, while witnessing the dialectics of political repression and steadfast revolt, of expansion of political (sovereign) power and intensive concentration of imaginative rebellion, that I felt compelled to take another -displaced- look at our memories of the events of 1989-1990. Or, should I say, rather, to return to the precedents of and the unprecedented moments in that history, and the history that followed. As the revolts in Hong Kong seemed to testify to in 2019, such re-turn might help us less to re-walk those earlier pathways backwards, or forward, than to reimagine them for the dispersed potentialities they have left for others to take up in other time(s).

The desire that animated the volume translated into the vision of it as an open, productive, collective and ongoing dialogue or forum, almost a living collage of recollections around "What if" moments, albeit beyond nostalgia: every text and image in this booklet, whether personal story, photograph, interview, short fiction, or academic essay, and whether composed in the here and now, a year or several years ago, as some are, proposes modes of imperfect, reflective recollections of the past as equally imperfect potentialities of and in the present. 
We know that the present is in desperate need of new recipes for ongoingness -in Haraway's words. ${ }^{23}$ It does not need utopias of totally unbound, unimaginably (and technologically) perfect human futures; in contrast- still in Haraway's phrase- it requires speculatively fabulated, and materially situated practices of (multispecies) worlding, where the imagination informs (again and again) acts of resistant cosmopolitanism and/or transnational solidarity. Something that has become particularly obvious with the spread in 2020 of the Covid-19 pandemic --or, as Slavoj Žižek put it, since the time a "stupid virus" ${ }^{24}$ has made us experience, on our human skin, how devastating the normalization of conditions of social and environmental injustice can be, injustice that has been brought on by unequal development and its economic mantras of growth on the one hand, and of "austerity"

${ }^{23}$ On the meaning of this term, see especially Haraway (2016). Eduardo Kohn offers a good recapitulation of the political use Haraway makes of ongoingness. First, ongoingness is the goal of Haraway's "Terran" (earthbound) temporality of otherworlding. Ongoingness is Haraway's response to the all too familiar utopian (or dystopian) investments in the future. The fantasy of "starting over and beginning anew" (Haraway 2016, 150, qtd in Kohn) is abandoned in favor of "the challenge ... to root that future in a way of being in a present fully informed by the past." (Kohn 99) Kohn explains: "Ongoingness as a temporal orientation is about 'learning to be truly present' in order to 'become capable of response' (p. 1), for example, we need to be able to dream well and remain fully awake. It is also about 'inherit[ing] without denial' (p. 150)." See Kohn, Dialogues in Human Geography, Vol 8, Issue 1 (February 2018, Online), pp. 99-101. Here 99. Online at: https: / / doi.org/10.1177/2043820617739206 Accessed 10 October 2020. When I refer to the future, I think of it within the framework of the temporality of ongoingness rather than that of utopia.

24 Slavoj Zižek, Pandemic!: Covid-19 Shakes the World (London: O/R Books, 2020),pp. 22, 88. 
(following the crisis of 2008) on the other. ${ }^{25}$ Ongoingness, in this sense, demands a courageous, adventurous, aesthetic and prismatic imagination that dares take up the challenge posed to its generative narratives by real-existing, material conditions of duress. In these increasingly unsupportable conditions, which over and over again wish to deny the imagination substance and materiality, the imagination has risen up, as every time pro-democracy protest movement around the world demonstrates. ${ }^{26}$

The thirty years since Tiananmen, in China, but also beyond China, in view of this power's rise on the world stage, seemed to me then, in that June 2019, to have brought additional evidence to the state of deep crisis of the model of Western liberal democracy. ${ }^{27}$ The "market economy" never discriminated between political forms of authoritarianism, with its shock therapy, whether through the support of coups in the Americas in the past, of the export of democracy post-9/11, and the ensuing war on

${ }^{25}$ Climate Change has of course shown this to be the case too, but the imperceptible scale of its impact on the privileged members of the Western World -up until recently, if one considers the recent wildfires in Australia and California-has allowed many to blissfully enjoy a state of self-imposed blindness.

${ }^{26}$ For a survey of protest movements just in 2019, see Bill Wanlund, "Global Protest Movements: Can they lead to lasting change?" CQ Researcher, Vol. 30, Issue 17, May 2020, npn. Online at

http:/ / library.cqpress.com/ cqresearcher/document.php?id=cqresrre 2020050100 Accessed 28 October 2020.

27 In this regard, Berlin and Hong Kong while far apart were Doppelgänger during the Cold War (and still are through inverted mirrors to an extent, today). See Jeffrey Wasserstrom, "The Divides that Make Hong Kong and West Berlin" in The Atlantic on February 24, 2020, npn.

Online

at https:/ / www.theatlantic.com/international/archive/2020/02/hongkong-berlin-protest-china/606211/ Accessed 13 October 2020. 
terrorism, or the erosion of the welfare states in Europe. It is democracy that neoliberal financial capitalism has disbanded. As Ida Dominijanni argued in a perspicacious article in July 2019, published in Internazionale, the traditional subjects of and in liberal democracy have emerged structurally changed by the $30-40$ years of encroachment of neoliberism upon liberal democracy, as the new sovereign populisms on the one hand and the special case of the ruling Chinese communist party on the other have well understood. ${ }^{28}$ Quite differently positioned on the spectrum of their critiques of democracy, yet with similar effects as far as state or sovereign nationalism's resurgence is concerned, these critiques of the liberal democratic forms of government have indeed been directed at the core ideas of liberalism and democracy: the rational subject; the people as constituents, i.e., being formed in the process of public participation in politics; the parties -a plurality of them-as the mediators and regulators of conflict; and the division of powers. Significantly, Viktor Orban, the prime minister of Hungary, thus commented on Trump's victory, on the $9^{\text {th }}$ of November, 2016, also the date of the fall of the Wall: "What a day! What a day! The liberal non-democracy has ended and I am freed of political correctness." Accordingly, he subsequently took the liberty to proceed with his own experiment of "illiberal democracy" which the European Union continued to believe could be reined in by virtue of the Union's solid liberal-democratic foundations.

${ }^{28}$ Ida Dominijanni, "La democrazia in Europa, trent'anni dopo il crollo del muro di Berlino," Internazionale, 9 July, 2019, npn. Online at https://www.internazionale.it/opinione/idadominijanni/2019/07/09/ democrazia-europa-muro-berlino. Accessed 9 February 2020. 
However, having the EU's foundations of (political) liberal democracy already having been ravaged by the EU's pursuit of a devastating neoliberist economy (see austerity and Greece), Dominijanni ascertains, the failure of democracy in the self-proclaimed liberal democratic states became the banner of anti-democratic, that is antigovernmental and populist, authoritarian (illiberal) movements and parties within Europe, Italy and the UK at the top of the list.

As this history has unfolded in the past 30-40 years since the end of the Cold War, people left and right have lost the "yardsticks" with which to measure the events, the world we live in. Such loss however cannot be left to those who wish to counter the loss of yardsticks with the metaphorical (and real) restoration of "readymade banisters" (of a neoclassical style), as Svetlana Boym, reprising Arendt, reminds us. (Boym 29) ${ }^{29}$

In light of the shift toward authoritarianism, right-wing extremism, and so on, the sustained remembrance of the "democratic" school that took place in 1989, as Christoph Hein and Christa Wolf put it, may refuel, through its displacement elsewhere, the fires that are needed now to imagine other "openings", to unfold other stories of and

\footnotetext{
${ }^{29}$ To mix metaphor and reality, in Berlin: the reconstruction (if not restoration) of the baroque Berliner Schloss (Berlin Castle), admittedly not built in "neoclassical" style, could still function as a good example of how a liberal democratic state-the FRG-asserts its return to a new "centrality" within Europe through the recourse to its glorious, precatastrophic, History. Interestingly, and quite paradoxically here, the Weimar Republic was proclaimed not just by Philipp Scheidemann at the Reichstag in Berlin, but also by Karl Liebknecht who did so from the Berlin Castle on the same day, the $9^{\text {th }}$ of November, 1918. The Emperor Wilhelm II went then into Exile. If one could believe in the ironies of history one would only hope that European democracy be reborn out of these old-new banisters ...
} 
around that year for a different present. This collection is a contribution in this direction. As expounded above in Cartographies I and Cartographies II, the volume proposes "What if" stories that are oriented towards an approximate future of possibilities and the possibility of a future. Our "What if" stories leave behind the history of "what is," perhaps, in the attempt to follow Arendt's injunction that one must "think without a banister". In Boym's interpretation of Arendt, such thinking involves an imaginative zigzagging -a real dance- through time. This is the very same dance, I opine, that the protest movements that have flourished and perished and come back again across the globe since 1989 have embodied. In this context, dancing is the balancing act between flight and fall which both joyfully and responsibly -in response to otherschoreographs the sharing of other-worlds. ${ }^{30}$ Those $21^{\text {st }}$

${ }^{30}$ I follow here Haraway's ideas of co-becoming, and the dance of relating in which all actors continuously become who they become with others, in worlds that are always co-constituted and "emergent". While Haraway focuses on acts of multispecies worlding; Judith Butler's theory of performative assembly carries over some of the same lines of thought into the explicit field of theories of radical democracies. In her book she props up precarity as the motive for contemporary protests, having precarity affected liveability. The radical and distinct openness proper to each protest and battle for democratic flourishing is the productive challenge at the core of ideas of history that leave behind all blueprints and determinism, as Buck-Morss argues in Revolution Today (2019). If, on the one hand, the course of history does not necessarily lead to progress; crises do not immediately yield democratic revolutions; and the revolutionary agents have not empirically been the working classes; on the other hand, failed attempts at social transformation are not disproven because of historical defeat. Empirical history, Buck-Morss argues, remains open to redemption (Ibid. 54, 62). To know this and to rescue the idea of revolution, or more "minimally" of social change, and/or crucially democracy, one must consider those fragments of the past that might "speak" from the 
century protests that are animated by the polyphonic music of democracy, and that embody democracy performatively, as a concerted movement of peaceful actions, show us that democracy is after all attainable, if, in the post-Cold War we have inherited, we take the past movement, the legacy of 1989 , and give it another spin.

The origins and the aim of this volume are thus, more or less political: in my view, the contributions imagine the thirtieth anniversarie(s) of 1989 (and 1990) "zigzagging" in ways that recollect the fragments that history has left behind or scattered elsewhere for other times to find. I wish this volume to abandon the triumphalist and unilinear accounts of German unification that have been at the core of the mainstream Europeanist ideology, since unification. ${ }^{31}$

future, and place them in a montage in the present. And such montage, as Covid-19 might help see even more than previously, may turn out to be humanity's gesture of reaching for the emergency-break on the train of a "what is" history, as Benjamin put it in his critique of Marx's metaphor for revolution. Montage is the space-time in the present of the "What-if" of history. For her part, Haraway underscores the need to cultivate" a radical ability to remember and feel what is going on and performing the epistemological, emotional, and technical work to respond practically in the face of the permanent complexity not resolved by taxonomic hierarchies and with no humanist philosophical or religious guarantees ... the open is not comfortable" (75). See When Species Meet (Minneapolis / London: UMP 2008); and Judith Butler, Notes toward a Performative Theory of Assembly (Cambridge, Mass: Harvard UP, 2015)

${ }^{31}$ In 1989 as media outlets of all kinds pointed out, the celebrations were more subdued than before, or at least scattered throughout the city of Berlin, emphasizing less than in the past the successful story of unification. In 2020, this was even more so, due to the Covid-19 Pandemic. Public ceremonies have been replaced by a plethora of online programmes on German TV, spanning a vast array of genres from feature films via documentaries to participatory sites for personal interventions, to time-documents, among others. The degrees of 
Rather, the collection turns to storytelling and the "anecdotal." These genres implicate partial vision and the recourse to empirical experience, which both, following Haraway and Wolf, in turn require inheriting the past without denying how it has shaped us, and with responseability toward the future. ${ }^{32}$ The volume thus turns to the present(s) and the pasts that ripple around the dates of 1989-1990. In these imperfect re-collections these dates and their anniversaries- remain somewhat subterranean. Other days of other years enter the frame. As illustrated in Cartographies I and II, the incidental temporalities and maps the contributions suggest in conversation with one another, help us to dislodge and reframe from with broader

\footnotetext{
"critical" positionings also varied. The splintering online of such celebrations while less triumphalist due to the lack of centrality does raise the question of whether a "channelization" of "individual" interests and information, if not the straightforward algorithm-based targeted distribution of reaffirming and reassuring "news" à la Facebook-- has supplanted any possibility of any democratic (in fact, genuinely political) dialogue concerning official reappraisals of contested histories.

32 I am referring here to Haraway's seminal essay "Situated Knowledges: The Science Question in Feminism and the Privilege of Partial Perspective," in Simians, Cyborgs, and Women: The Reinvention of Nature (New York: Routledge, 1991), pp. 183-201. There she speaks of a feminist objectivity that is "about limited location and situated knowledge, not about transcendence and splitting of subject and object. In this way, we might become answerable for what we learn to see." (Ibid 190). Objectivity turns out to be about particular and specific embodiment. She adds: "The moral is simple: only partial perspective promises objective vision. ... Partial perspective can be held accountable for all its promising and destructive monsters." (Ibid) In Haraway's words being situated means: "to remain attuned to specific historical and political positionings and permanent partialities without abandoning the search for potent connections." (Ibid 1) On Wolf's "Subjective Authenticity" see footnote 15 above.
} 
contexts the genealogy and the repercussions of 1989-1990. Through the fragments -or scattered images-found and proposed here, the book inaugurates a process of recognition (to know again) of the mistakes, illusions, mishaps and misunderstandings, as well as of the paradoxes that have marked our time.

But let me return, in closing, to the $30^{\text {th }}$ anniversaries of Tiananmen and the Peaceful Revolution. Jeffrey Wasserstrom reminded us following the commemorations of Tiananmen Square that took place in Hong Kong in June 2019, that on that day in 1989, The New York Times announced on its front page the unlikely victory of another protest movement on the opposite side of the world from Beijing, where the protests had been squashed. That movement was Solidarnosc. Wasserstrom makes the point, akin to mine here in reference to the Peaceful Revolution in Germany, in 1989, that if the Tiananmen tragedy is worth commemorating and mourning -and even more so from the precarious position of Hong Kong citizens whose freedoms are threatened and impinged upon - so, too, is the unlikely victory of Solidarity -or the Peaceful Revolution, at that same time. Indeed, as Wasserstrom argues in his article, the protesters in Hong Kong have much to share with Solidarnosc and its unlikely victory. If the shadow Beijing casts is "lengthening rather than lightening, under a leader more bent on controlling all under his domain than China has seen in decades," Wasserstrom concludes "yet, one thing that the histories of Poland and Hong Kong alike remind us is that completely unexpected things can happen." (Ibid) History is, indeed, open.

The official anniversaries of 9 November 1989, and again of 3 October 1990 (the Day of Unification), therefore, are celebrated here in the name of "What-if" stories for the 
ongoingness of openings and openness in history. And finally, in their own "minor" "imperfect" acts of recollection, the contributions intend less to take stock, in the present, of the time that has passed since that year, than to rethink how our singular, and particular sociobiographical ways of relating to the worlds we share might indeed have crossed paths with, been shaped by or, alternatively, diverted by that larger framework of history: to reflect in short on how we have become "those" we are. 


\section{Works Cited}

Berlin Events. Website.

https://www.berlin.de/en/tickets/ concerts/alexander -scheer-andreas-dresen-band-gundermann-fba5645e6f1e-407e-b772-61e70df9e70b/ Accessed 26 October 2020.

Bivens, Hunter. "Our Short Life: Building and Dwelling in Late Socialism." npn.

https: / / ecommerce.umass.edu/defa/ sites/default/ file s/Our\%20Short\%20Life\%20-

$\%$ 20Building $\% 20$ and $\%$ 20Dwelling $\% 20$ in $\% 20$ Late $\% 20$ So cialism $\% 281 \% 29 \% 20$ copy.pdf

Borger, Julian. "Republicans closely resemble autocratic parties in Hungary and Turkey - study," The Guardian, 26 October 2020, npn.

https: / / www.theguardian.com/us-

news/2020/oct/26/republican-party-autocratic-

hungary-turkey-study-trump. Accessed 26 October, 2020.

Boyer, Dominic. " From Algos to Autonomos: Nostalgic Eastern Europe as Postimperial Mania." Post-communist Nostalgia, edited by Maria Todorova and Zsuzsa Gille (Berghahn Books), pp.

17-28. https: / / www.jstor.org/stable/j.ctt9qd8t4.5 Accessed 20 October, 2020. Accessed 25 October 2020.

Boym, Svetlana. Another Freedom: The Alternative History of an Idea. Chicago: Chicago UP, 2010.

Buck-Morss, Susan. Dreamworld and Catastrophe: The Passing of Mass Utopia in East and West. Cambridge, Mass and London: MIT Press 2000.

- Revolution Today. Chicago: Haymarkets Books, 2020. Butler, Judith. Notes toward a Performative Theory of Assembly. Cambridge, Mass: Harvard UP, 2015. 
Chan, Cora. "Thirty years from Tiananmen: China, Hong Kong, and the ongoing experiment to preserve liberal values in an authoritarian state" International Journal of Constitutional Law. Vol. 17, no. 2, 2019, pp. 439-452. https: / / ssrn.com/abstract=3453130. Accessed 9 October 2020.

Dominijanni, Ida. "La democrazia in Europa, trent'anni dopo il crollo del muro di Berlino." Internazionale, 9 July, 2019, npn.

https: / / www.internazionale.it/opinione/idadominijanni / 2019/07 / 09/ democrazia-europa-muroberlino. Accessed February 9, 2020.

European Film Awards. Website.

https: / / europeanfilmawards.eu/en EN/film/gunder mann.13137 Accessed 26 October 2020.

Grafton, Anthony. The Footnote: A Curious History. Cambridge, Mass: Harvard UP 1999.

Gundermann. Director Andreas Dresen. Perf. Alexander Scheer, Anna Unterberger. Screenplay by Laila Stieler. Produced by Claudia Steffen, Christoph Friedel. 2018. DVD.

Haraway, Donna. "Situated Knowledges: The Science Question in Feminism and the Privilege of Partial Perspective." Simians, Cyborgs, and Women: The Reinvention of Nature. New York: Routledge, 1991, pp. 183-201.

-When Species Meet. Minneapolis and London: UMP 2008.

Staying with the Trouble: Making Kin in the Chthulucene. Durham and London: Duke UP, 2016.

Hein, Christoph. Willenbrock. Frankfurt/M: Suhrkamp, 2001.

Huyssen, Andreas. Present Pasts: Urban Palimpsests and the Politics of Memory. Palo Alto: Stanford UP, 2003. 
Jampol Justinian. "GDR on the Pacific: (Re)presenting East Germany in Los Angeles." Art Outside the Lines: New Perspectives on GDR Art Culture, edited by Elaine Kelly and Amy Wlodarski. Amsterdam, New York: Rodopi, 2011.

Kohn, Eduardo. "What kind of world can what kind of we world? Staying with Donna Haraway's Staying with the Trouble." Dialogues in Human Geography, vol. 8 no. 1, pp. 99-101.

Leopardi, Giacomo. Zibaldone. Originally published in Italian in 1898. Edited by Michael Caesar, Franco D'Intino et. al. New York: Farrar, Straus and Giroux, 2013.

Leusink, Andreas. Gundermann: Von jedem Tag will ich was haben, was ich nicht vergesse ... Briefe, Dokumente, Interviews, Erinnerungen. Berlin: Christoph Links Verlag, 2018.

Magenau, Jörg. Christa Wolf. Eine Biographie. Berlin: Kindler 2002.

Museum Fatigue. BLOG. https: / museumfatigue.org/2020/04/09/makingstring-figures-amid-the-troubles-on-zoom/ Accessed 23 October 2020.

Paulson, Steve. "Making Kin: an Interview with Donna Haraway." Los Angeles Review of Books. December 6, 2019. npn. Online at https: / / lareviewofbooks.org/article/making-kin-aninterview-with-donna-haraway / Accessed 23 October 2020.

Schaefer, Derek. East German Literature in the 21st Century: Minor Literature and Alternative Memory. PhD Dissertation. Chicago: University of Illinois, 2016.

Wanlund, Bill. "Global Protest Movements: Can they lead to lasting change?" CQ Researcher, vol.30, no.17, May 
2020, npn.

http: / / library.cqpress.com/cqresearcher/document.ph p?id=cqresrre2020050100 Accessed 28 October 2020.

Wasserstrom, Jeffrey. "The Divides that Make Hong Kong and West Berlin." The Atlantic. February 24, 2020, npn. https: / / www.theatlantic.com/international/archive/ 2 020/02/hong-kong-berlin-protest-china/606211/

Accessed on 13 October 2020.

Willenbrock. Director Andreas Dresen. Perf. Axel Prahl, Inka Friedrich, Anne Ratte Polle etc. Screenplay by Laila Stieler. Produced by UFA Filmproduktion. 2005. DVD. Wolf, Christa. "Subjective Authenticity: A Conversation with Hans Kaufmann." Responses to Christa Wolf, edited by Marilyn Sibley Fries. Detroit: Wayne State UP, c.1989, 1993, pp

-----. City of Angels: Or, The Overcoat of Dr Freud. Translated by Damion Searls (New York: Farrar, Straus \& Giroux, 2013).

Žižek, Slavoj. Pandemic!: Covid-19 Shakes the World. London: O/R Books, 2020. 